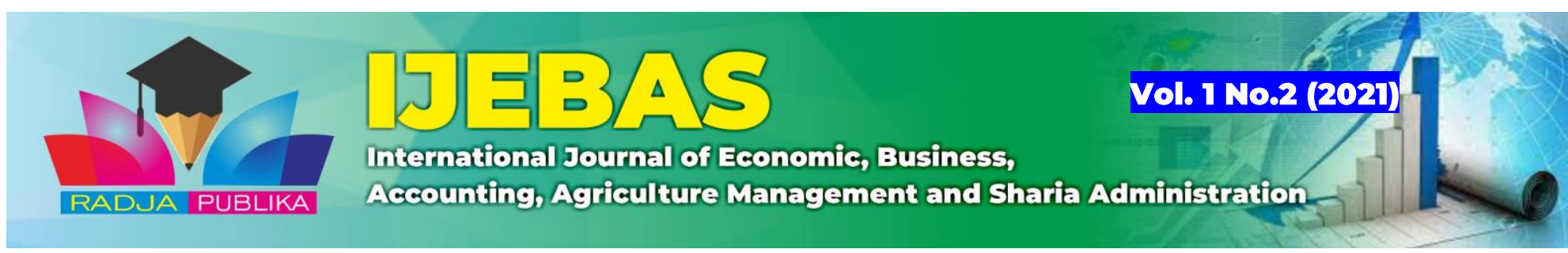

\title{
MAPPING VALUE ADDED ARABICA COFFEE PROCESSED PRODUCTS IN ACEH TENGAH
}

\author{
Fadli $^{1}$, Emmia Tambarta Kembaren ${ }^{2}$, Irada Sinta ${ }^{3}$ \\ Faculty of Agriculture, Universitas Malikussaleh \\ E-mail: emmia.tambarta@unimal.ac.id
}

\begin{abstract}
Coffee is one of the plantation commodities that has an important role in foreign trade. In 1712, Indonesian coffee plantations were traded for the first time to the Netherlands (KP Gayo, 2016). Aceh coffee, which is better known internationally is the type of Gayo Arabica coffee because it has a distinctive aroma and taste. This research uses descriptive quantitative research methods. This research was conducted in Aceh Tengah. This is because Aceh Tengah is one of the main production Aceh Tengah. The objects of this research are the trade office, the agriculture office, coffee expert staff, Gayo arabica coffee farmers and the four green been coffee agroindustry and coffee grounds which have the largest export quotas in Bener Meriah Regency, namely KBQ Baburrayyan, Oro Coffee Cooperative, and PT Olam Coffee. The data collection method used is in-depth interviews with several key persons belonging to the research object. The results showed that the output value obtained from pumpkin coffee products was Rp. 27,176 per Kg with an added value of Rp. 22,176 per $\mathrm{Kg}$. The output value obtained from green bean products is $\mathrm{Rp} .56,950 / \mathrm{Kg}$ with an added value of Rp. 13,050/Kg. The output value obtained from the Gayo Arabica coffee powder product is Rp. $123.500 / \mathrm{Kg}$ with an added value of $\mathrm{Rp} .36 .500 / \mathrm{Kg} .176 \mathrm{per} \mathrm{Kg}$ with an added value of Rp. 22,176 per $\mathrm{Kg}$. The output value obtained from green bean products is $\mathrm{Rp} .56,950 / \mathrm{Kg}$ with an added value of Rp. 13,050/Kg. The output value obtained from the Gayo Arabica coffee powder product is $R p$. $123.500 / \mathrm{Kg}$ with an added value of $\mathrm{Rp} .36 .500 / \mathrm{Kg}$. $176 \mathrm{per} \mathrm{Kg}$ with an added value of $\mathrm{Rp} .22,176$ per $\mathrm{Kg}$. The output value obtained from green bean products is $\mathrm{Rp} .56,950 / \mathrm{Kg}$ with an added value of Rp. 13,050/Kg. The output value obtained from the Gayo Arabica coffee powder product is Rp. $123.500 / \mathrm{Kg}$ with an added value of Rp. 36.500/Kg.
\end{abstract}

Keywords: Gayo Arabica Coffee, Processing, Added Value.

\section{INTRODUCTION}

Coffee is one of the plantation commodities that has an important role in foreign trade. In 1712, Indonesian coffee plantations were traded for the first time to the Netherlands (KP Gayo, 2016). According to AEKI (2020), currently Indonesia is classified as the fourth largest coffee exporting country in the world after Brazil, Vietnam and Colombia. The level of competition between competitors in world coffee exports is relatively high because the coffee industry has entered the maturity stage at the peak of the industrial life cycle, so that competitors will continue to compete for development, both in raw coffee and coffee derivatives. The existence of Indonesian coffee competitors such as Brazil, Colombia and Vietnam will affect the competitive position of Indonesian coffee in the international market.

Aceh coffee, which is better known internationally is the type of Gayo Arabica coffee because it has a distinctive aroma and taste. The name Gayo Arabica coffee arises because the Arabica coffee with the best taste comes from the Gayo highlands, namely the districts of Aceh Tengah and Bener Meriah as shown in the following picture: 


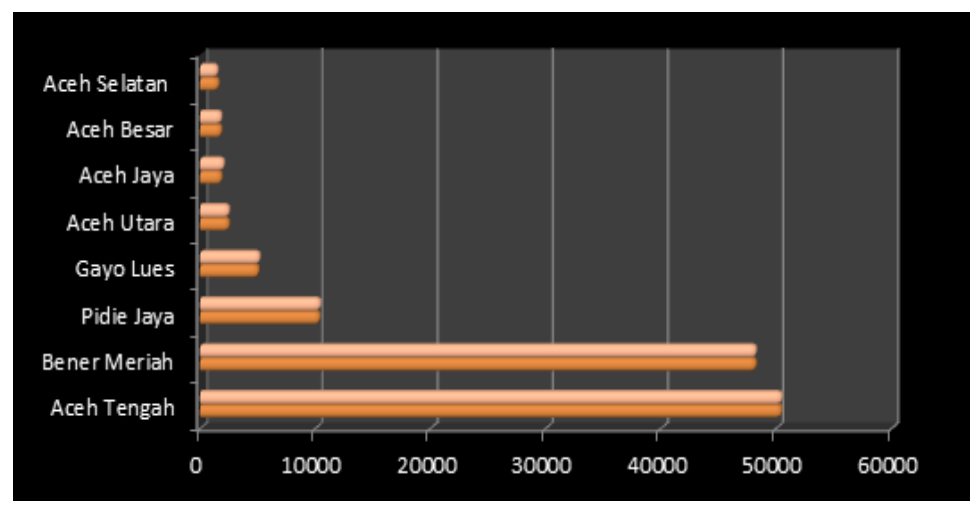

(Source: BPS 2019)

The graph above shows that there are eight districts that are centers of coffee production in Provinsi Aceh. Aceh tengah is a production center with the largest land area among the six districts (BPS Aceh Tengah, 2020). The data above shows that Aceh Tengah has enormous potential to develop Gayo Arabica coffee. This opportunity can certainly be the main basis for the process of developing Gayo coffee products into various processed products such as coffee powder, instant coffee or other processed coffee products. However, until now, the competitiveness and added value of Gayo coffee is still lagging behind other major coffee producing countries in the world, which is still limited to green beans. Whereas, The current competitive conditions for the coffee market are getting tighter where each country develops their coffee processed products from each other. The strategy for developing Arabica coffee commodities today is expected to be no longer how to increase production, but how a commodity can be processed so that added value is obtained from the processing process.

Saragih (2010) revealed that the added value obtained from the development of processed products (downstream) is much higher than primary products, so the future agricultural development approach is directed at product development, and is no longer focused on commodity development. The development of value-added products is carried out through the development of industries that process primary agricultural products into processed products, both intermediate products, semifinished products and most importantly competitive final products.

Through this research, it is hoped that Gayo coffee will not only be marketed as raw or semifinished ingredients. The development of processed coffee should be more focused on increasing the added value of Gayo coffee processed products. The development of added value in coffee commodities is expected to produce diversified processed coffee products, such as roasted coffee, instant coffee, coffee mix, and decaffeinated coffee which have important meaning, because they can become superior commodities that have high competitiveness in the international market. The increase in added value in terms of product types will support the development of processed coffee so that it can compete in the international market system. The increase in product processing innovation is certainly expected to increase the added value of Gayo coffee processed products, which consist of premium, specialty, and green beans. and specialty coffee grounds, kaskaras and other products. The calculation of added value must be done based on the type of product, because each type of product certainly has a different level of added value. 


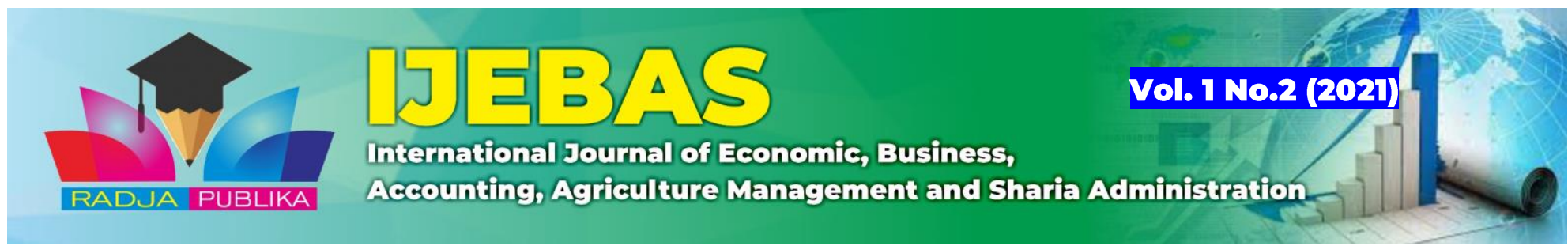

\section{RESEARCH METHOD}

This research uses descriptive quantitative research methods. This research was conducted in Central Aceh District. This is because Aceh Tengah is one of the main production centers in Aceh. The object of this research is Gayo Arabica Coffee industry players who have a Gayo Arabica coffee culinary business. The data collection method used was in-depth interviews with several key persons, namely: the trade office, the agriculture office, coffee expert staff, Gayo arabica coffee farmers and four green been coffee agroindustry and coffee grounds which have the largest export quota in Bener Meriah Regency, namely KBQ Baburrayyan., Cooperative Oro Coffee, and PT Olam Coffee. Each of these agroindustry will be analyzed cost, revenue, profit to get the calculation of added value of agroindustry based on the type of product and its processing. This study uses the Hayami method to analyze the added value. The calculation of this added value is based on one unit of the main raw material. There are several variables involved in this value added analysis. Conversion factor, shows the number of processed products produced from one kilogram of raw materials. The labor coefficient, shows the amount of direct labor required to process one unit of input. While the value of the product shows the value of the output generated from one unit of input. Conversion factor, shows the number of processed products produced from one kilogram of raw materials. The labor coefficient, shows the amount of direct labor required to process one unit of input. While the value of the product shows the value of the output generated from one unit of input. Conversion factor, shows the number of processed products produced from one kilogram of raw materials. The labor coefficient, shows the amount of direct labor required to process one unit of input. While the value of the product shows the value of the output generated from one unit of input.

\section{RESULTS AND DISCUSSION}

Processing of products is an agribusiness sub-sector that has a very large role in increasing the added value of agricultural products that have been obtained. In economic conditions where the industrial sector must be developed in a balanced manner with the development of other sectors such as the agricultural sector which supports the industrial sector. The goal is to improve and improve people's living standards to be more secure and feasible (Soekartawi, 2016). Processing can be defined as an industrial activity that uses raw materials derived from primary agricultural products to be processed into semi-finished products or finished goods that can be consumed. Sembiring (2015) in his research explains that there are two types of processing that are most often carried out by coffee farmers, namely wet processing and dry processing. At the beginning of the development of coffee in the Gayo Highlands in the 1950s, most farmers used the dry processing process, because it was easier for them. However, in the 1980s, as markets continued to expand and economic actors from outside Aceh continued to grow, wet processing grew in popularity. Currently, most of the Arabica coffee beans in Aceh Tengah Regency are processed using the semi-washed (semi-wet) and washed (wet) methods. Only a few areas use dry processing systems (dry). Currently, most of the Arabica coffee beans in Aceh Tengah Regency are processed using the semi-washed (semi-wet) and washed (wet) methods. Only a few areas use dry processing systems (dry). Currently, most of the Arabica coffee beans in Aceh Tengah Regency are processed using the semi-washed (semi-wet) and washed (wet) methods. Only a few areas use dry processing systems (dry).

The washed system requires more water because the washing process is repeated. For most places that are difficult to reach water, the semi-washed system is more widely used because it does not require as much water as the washed system. The special taste of Gayo Arabica coffee is the presence of a sour taste that resembles the acidity of lime. The distinctive taste of Gayo coffee is known to be thicker with a very distinctive color aroma. Roasted seeds are usually dark brown with a white groove in the middle of the seeds. (Susanti, 2018). The added value in the process of pumpkin 


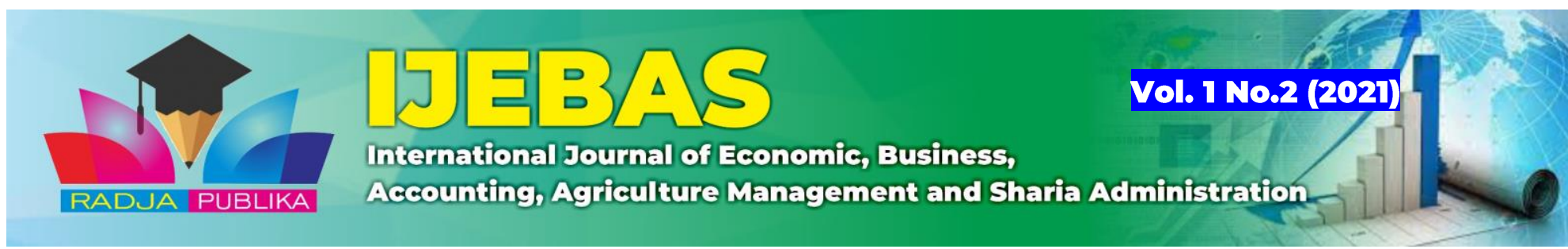

coffee beans to green coffee beans in Aceh Tengah is higher at Rp. $28.337 / \mathrm{Kg}$ with a ratio of $38.40 \%$ green beans coffee in Bener Meriah Regency is Rp. $26.738 / \mathrm{Kg}$ with a ratio of $37.14 \%$. In general, the processing of coffee beans in the research area is as follows: a) Dry Processing method. This method is very simple and ie directly dry the coffee cherries that have been harvested. c) Semi Washed and Washed (wet) Processing method

Process Method Wet treatment usually uses more water than dry and semi washed treatment systems. In general, the semi-washed and washed processes are almost the same. The only difference between the two is the washing process. The washing process in the washed system is carried out repeatedly. Most of Central Aceh District uses a semi washed processing system which includes; the collection of coffee cherry beans, washing, fermentation, the process of stripping the cherry seeds into pumpkin seeds, grading, and drying are carried out by the assisted farmers. Gayo Arabica coffee processing can be seen in the following picture:

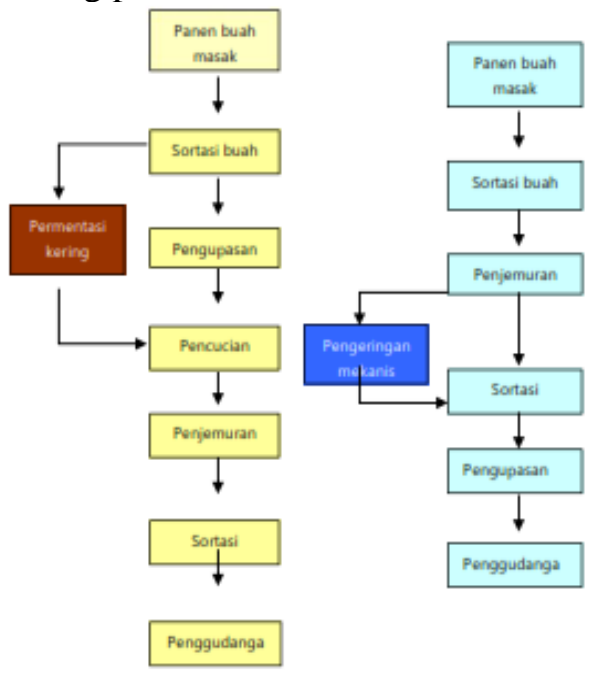

Figure 1. Gayo Arabica Coffee Processing

The processing techniques carried out by the processing industry mostly use machines, only 1 or 2 use human power to control the machine. ), huller and other machines. For the process of sorting coffee beans manually by the industry. Coffee processing by fostered farmers must be carried out in the right time, in the right way and in the right amount. Harvested coffee cherries, like other agricultural products, need to be processed into a stable final form so that they are safe for storage for a certain period of time. Coffee bean quality criteria which include physical, taste and cleanliness as well as aspects of uniformity and consistency are largely determined by the treatment at each stage of the processing process. Dry processing is basically imitating natural processes (natural processing). Dry processing is usually used to produce natural/honey coffee beans which are included in the specialty coffee bean category based on the processing process.

Cooperatives generally use Arabica coffee beans as raw materials with a certain ratio composition. Arabica coffee is used as a source of flavor image. Arabica coffee has a better taste and less caffeine than Robusta coffee. In addition to coffee beans, the coffee processing industry also requires additional materials such as sugar, corn, and others; as well as auxiliary materials such as packaging materials (packing), pallets, crates and others. In general, the processed Gayo Arabica coffee beans in the KBQ Baburrayan cooperative and the coffee refinery are divided into four namely: (1) Labui Coffee Beans, (2) Green Coffee Beans, (3) Coffee Powder. Cherry beans or red 
coffee beans are coffee beans that have just been harvested and have not undergone any processing. while coffee grain is a coffee bean product obtained from the processing of cherry beans. The added value in the grain production system is determined by the quality of the cherry red coffee (cherry), soaking and fermenting, the pulping process, the use of drying equipment and facilities, and the skills of the workforce who carry out each phase of the activity. The added value obtained will be greater if the red cherries are densely processed, using standard pulper equipment and supporting facilities, and carried out by skilled workers. and skills of the workforce performing each phase of the activity. The added value obtained will be greater if the red cherries are densely processed, using standard pulper equipment and supporting facilities, and carried out by skilled workers. and skills of the workforce performing each phase of the activity. The added value obtained will be greater if the red cherries are densely processed, using standard pulper equipment and supporting facilities, and carried out by skilled workers.

Labui coffee beans are coffee bean products obtained from the processing of coffee grain beans. The processing process is the process of stripping the epidermis using a Huller machine and then washing it several times. The added value in the pumpkin coffee bean production system is determined by the quality of the coffee grain, the hulling process, the washing process, the use of grain drying equipment and facilities, and the skills of the workforce who carry out each phase of the activity. The added value obtained will be greater if the coffee beans are processed densely, using huller equipment and standard supporting facilities, and carried out by skilled workers. Processing of Gayo Arabica unhulled coffee beans into pumpkin seeds is carried out by the industry which is divided into the Cooperative and the Coffee Refinery. The added value to the green bean coffee bean production system is determined by the quality of the pumpkin beans, the drying process until it reaches a moisture content of $12-15 \%$, the manual or mechanical grading and sorting process as well as the skills of the workforce who carry out each phase of the activity. The distribution of the value added map of processed coffee products can be seen in the following table:

Table 1. Mapping of Added Value of Gayo Arabica Coffee Processed Products in Aceh Tengah in 2020

\begin{tabular}{|c|c|c|c|c|c|}
\hline Variable & Unit & Notation & Labui & Green Beans & Powder \\
\hline \multicolumn{6}{|l|}{ Output, input and price } \\
\hline Output & $\mathrm{kg} /$ year & A & $1,872,900$ & $18,552,950$ & 43,605 \\
\hline Raw material input & $\mathrm{kg} / \mathrm{year}$ & B & $34,609,000$ & $21,827,000$ & 45,900 \\
\hline Labor input & $\mathrm{HOK} /$ year & $\mathrm{C}$ & $3,291,200$ & $1,843,200$ & 2.650 \\
\hline Conversion factor & $\begin{array}{l}\text { Kg output/Kg raw } \\
\text { material }\end{array}$ & $\mathrm{D}=\mathrm{a} / \mathrm{b}$ & 0.63 & 0.85 & 0.95 \\
\hline Labor coefficient & $\begin{array}{l}\mathrm{HOK} / \mathrm{Kg} \text { of } \\
\text { raw material }\end{array}$ & $\mathrm{E}=\mathrm{c} / \mathrm{b}$ & 0.095 & 0.084 & 0.058 \\
\hline Output Price & $\mathrm{Rp} / \mathrm{Kg}$ & $\mathrm{F}$ & 43,000 & 67,000 & 130,000 \\
\hline Labor average wage & $\mathrm{Rp} /$ Working Hour & G & 6.250 & 8,750 & 8,750 \\
\hline \multicolumn{6}{|l|}{ Income and Profit } \\
\hline Raw material input price & $\mathrm{Rp} / \mathrm{Kg}$ & $\mathrm{H}$ & - & 43,000 & 67,000 \\
\hline Other input contributions & $\mathrm{Rp} / \mathrm{Kg}$ & I & 5,000 & 900 & 20,000 \\
\hline Output Value & $\mathrm{Rp} / \mathrm{Kg}$ & $\mathrm{J}=\mathrm{dxf}$ & 27,176 & 56,950 & 123,500 \\
\hline Value-added & $\mathrm{Rp} / \mathrm{Kg}$ & $\mathrm{K}=\mathrm{jhi}$ & 22.176 & 13.050 & 36,500 \\
\hline Value added ratio & $\%$ & $\mathrm{~L}=\mathrm{k} / \mathrm{j} \times 100 \%$ & 81.60 & 22.91 & 29.55 \\
\hline Labor income & $\mathrm{Rp} / \mathrm{Kg}$ & $M=\operatorname{exg}$ & 594 & 739 & 505 \\
\hline Labor section & $\%$ & $\mathrm{~N}=\mathrm{m} / \mathrm{kx} 100 \%$ & 2.68 & 5.66 & 1.38 \\
\hline Profit & $\mathrm{Rp} / \mathrm{Kg}$ & $\mathrm{O}=\mathrm{k}-\mathrm{m}$ & 21.582 & 12.311 & 35,995 \\
\hline Profit Section & $\%$ & $\mathrm{P}=\mathrm{o} / \mathrm{j} \mathrm{x} 100 \%$ & 79.41 & 21.62 & 29.15 \\
\hline
\end{tabular}




\begin{tabular}{llllcc} 
Variable & Unit & Notation & Labui & Green Beans & Powder \\
a. Labor income & $\%$ & $\mathrm{R}=\mathrm{m} / \mathrm{qx} 100 \%$ & 2.19 & 5.30 & 0.89 \\
b. Other input contributions & $\%$ & $\mathrm{~S}=\mathrm{i} / \mathrm{lx} \mathrm{100 \%}$ & 18,40 & 6.90 & 54.79 \\
c. Profit & $\%$ & $\mathrm{~T}=\mathrm{o} / \mathrm{qx}$ 100\% & 79.41 & 88.25 & 63.71 \\
\hline
\end{tabular}

The added value formed will be determined by the comparison of the purchase price of raw materials and product prices. The results showed that the purchase price of red logs in Aceh Tengah in 2020 was IDR 0 per kg of red logs. This is because the party who gets the percentage of added value is the farmer who cultivates the coffee itself, so that the raw materials are not purchased but are cultivated themselves. Cultivation costs will be calculated in the contribution of other inputs, which is Rp. $5,000 / \mathrm{Kg}$. The cost components for other inputs consist of purchasing seeds/Kg, fertilizing $/ \mathrm{Kg}$ and infrastructure $/ \mathrm{Kg}$ of coffee produced. The price of pumpkin output is $\mathrm{Rp} .43,000 \mathrm{per} \mathrm{Kg}$. The conversion factor for pumpkin coffee production is 0.63 which means that each processing of $1 \mathrm{Kg}$ of cherry seeds will produce $0.63 \mathrm{Kg}$ of pumpkin coffee.

The output value obtained from pumpkin coffee products is $\mathrm{Rp} 27,176$ per $\mathrm{Kg}$ with an added value of $\mathrm{Rp} 22.176$ per $\mathrm{Kg}$. Based on the added value ratio formed, it can be seen that farmers get the largest added value share, which is $81.60 \%$. This means that Gayo Arabica coffee farmers get quite a high profit from the processing of pumpkin coffee. The value of remuneration for production factors can be calculated from the comparison of the contribution of production factors with added value. Remuneration for factors of production is the value formed from the contribution of labor and other factors of production. The three components of remuneration that Hayami takes into account (year ), are labor income, contribution of other inputs and income. The process of processing cherry seeds into pumpkin coffee is labor intensive. The purchase of pumpkin as a raw material in Aceh Tengah has experienced ups and downs.

Furthermore, the purchase price of pumpkin in Aceh Tengah in 2020 is IDR 43,000 per kg. The party that gets the added value percentage is the processing industry such as the KBQ Baburrayya Cooperative etc. The cost of processing/Kg which consists of the cost of grading, sorting, drying, quality assurance and packaging will be calculated on the contribution of other inputs, which is $\mathrm{Rp} .900 / \mathrm{Kg}$. The output price of green beans is IDR 67,000 per $\mathrm{kg}$. The conversion factor for pumpkin coffee production is 0.85 , which means that each processing of $1 \mathrm{Kg}$ of pumpkin seeds will produce $0.85 \mathrm{Kg}$ of green coffee beans. The output value obtained from green bean products is $\mathrm{Rp} 56.950 / \mathrm{Kg}$ with an added value of

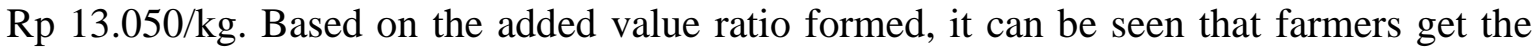
largest added value share, which is $22.91 \%$ per Kg. Furthermore, the gayo arabica coffee industry in Central Aceh gets a profit of $21.62 \%$ per $\mathrm{Kg}$ of each production process.

Then for the purchase price of green beans in Aceh Tengah in 2020 is IDR 67,000 per kg. The party that gets the added value percentage is the advanced industry party such as CV or Coffee Shop etc. Processing costs/Kg consisting of grinding and packaging costs will be calculated on the contribution of other inputs, which is Rp. $20,000 / \mathrm{Kg}$. The output price of green beans is Rp. $130.000 / \mathrm{Kg}$. The conversion factor for pumpkin coffee production is 0.95 which means that every $1 \mathrm{~kg}$ of green bean coffee processing will produce $0.95 \mathrm{~kg}$ of coffee grounds. The output value obtained from Gayo Arabica coffee powder products is $\mathrm{Rp} 123,500 / \mathrm{Kg}$ with an added value of $\mathrm{Rp} 36,500 / \mathrm{kg}$. Based on the added value ratio formed, it can be seen that farmers get the largest added value share, which is $29.55 \%$ 


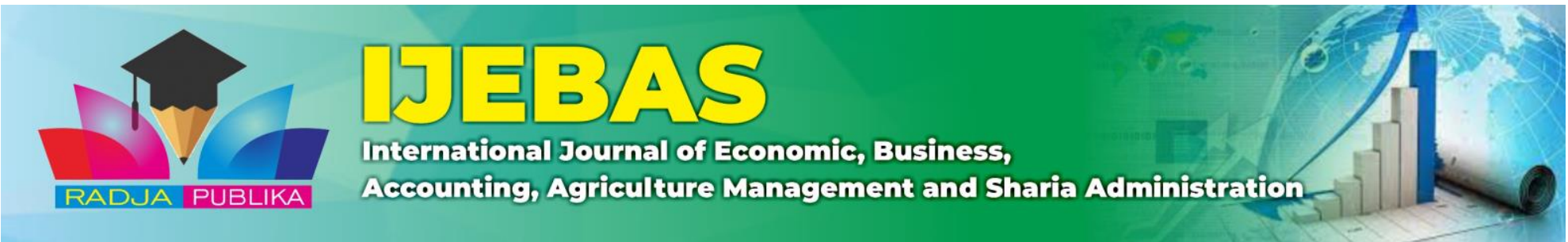

per Kg. Furthermore, the Gayo Arabica coffee industry in Central Aceh received a profit of $29.15 \%$ per $\mathrm{Kg}$ of each production process.

\section{CONCLUSION}

The output value obtained from pumpkin coffee products is Rp. 27,176 per Kg with an added value of Rp. 22,176 per $\mathrm{Kg}$. Based on the added value ratio formed, it can be seen that farmers get the largest added value share, which is $81.60 \%$. This means that Gayo Arabica coffee farmers get quite a high profit from the processing of pumpkin coffee. The output value obtained from green bean products is Rp. 56,950/Kg with an added value of Rp. 13,050/Kg. Based on the added value ratio formed, it can be seen that farmers get the largest added value share, which is $22.91 \%$ per $\mathrm{Kg}$. Furthermore, the gayo arabica coffee industry in Central Aceh gets a profit of $21.62 \%$ per $\mathrm{kg}$ from each production process. The output value obtained from the Gayo Arabica coffee powder product is Rp. $123.500 / \mathrm{Kg}$ with an added value of $\mathrm{Rp} .36 .500 / \mathrm{Kg}$. Based on the added value ratio formed, it can be seen that farmers get the largest added value share, which is $29.55 \%$ per Kg. Furthermore, the Gayo Arabica coffee industry in Central Aceh gets a profit of $29.15 \%$ per kg from each production process.

\section{REFERENCE}

[AEKI] Asosiasi Eksportir Kopi Indonesia. 2020. Laporan Pasar Kopi. Jakarta (ID) : AEKI.

[BPS] Badan Pusat Statistik Aceh Tengah. 2019. Aceh Dalam Angka. Provinsi Aceh: BPS.

Hayami, Y., Kawagoe, T., \& Morooka, Y. (1987). Agricultural Marketing and Processing in Upland Java A Perspective From A Sunda Village (Masdjidin Siregar (ed.); 8th ed.). Bogor: CGPRT Center.

Kebun Percobaan Kopi Gayo. 2016. Kopi Gayo. Modul. Bener Meriah

Saragih, B. 2010. Suara Agribisnis : Kumpulan Pemikiran Bungaran Saragih. Jakarta: PT Permata Wacana Lestari.

Sembiring, N., I K. Satriawan, dan I A. M. Tuningrat. 2014. Nilai Tambah Proses Pengolahan KopiArabika Secara Basah (West Indischee Bereding) dan Kering (Ost Indischee Bereding) DiKecamatan Kintamani, Bangli. Jurnal Rekayasa Dan Manajemen Agroindustri Vol (4).

Soekartawi. 2016. Analisis Usahatani. Jakarta : UI-Press.

Sudjarmoko, B. 2013. Prospek Pengembangan Industrialisasi Kopi Indonesia. Sirinov, 1(3), 99-110.

Sugiyono. 2011. Metode Penelitian Kuantitatif Kualitatif dan R\&D. Bandung: Alfabeta.

Susanti A.A, Akbar, 2018. Outlook Kopi. Jakarta: Kementrian Pertanian.

Tambarta, E., Tinaprilla, N., \& Adhi, A. K. (2016). Analysis Added-ValueAnd Development Strategic of Gayo Coffe Products in Bener Meriah Aceh. 5(11), 515-519. 


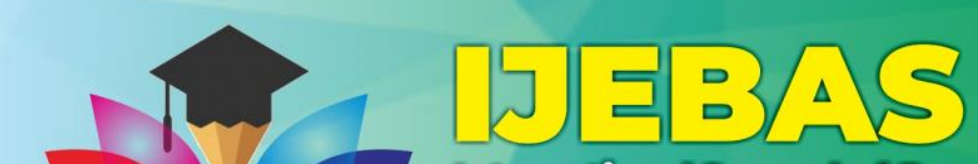

Thternational Joumal of Economic, Business, 